\title{
ROOT AERATION IMPROVES YIELD AND WATER USE EFFICIENCY OF IRRIGATED POTATO IN SANDY CLAY LOAM SOIL
}

\author{
M. E. Abuarab*, Mohamed M. Shahien ${ }^{* *}$, E. Mostafa****
}

\begin{abstract}
A field study was conducted in 2013 and 2014 to evaluate the effect of air-injection into the irrigation stream in subsurface trickle irrigation on the productivity of potato. The growth characteristics, yield and water use efficiency (WUE) of potatoes grown in a sandy clay loam soil with subsurface trickle irrigation with an air-injection treatment were compared with those of potatoes grown under a conventional trickle and subsurface trickle irrigation as a control. The yield was $27.11 \%$ and $17.8 \%$ greater, in the air injection treatment comparing with non-aerated treatments trickle irrigation (DI) and subsurface trickle irrigation (SDI) respectively, for the first season, while it was greater by $38.2 \%$ and $7.66 \%$ than DI and SDI, respectively, for the second season. The WUE was $46.41 \%$ and $30.52 \%$ greater, in the air injection treatment comparing with non-aerated treatments (DI) and (SDI) respectively, for the first season, while it was greater by $61.78 \%$ and $19.33 \%$ than DI and SDI, respectively, for the second season. The plant height was $14.7 \%$ and $6.07 \%$ greater, in the air injection treatment than in the control (DI) and (SDI) respectively, for the first season, while it was greater by $14.13 \%$ and $9.7 \%$ than in the control for the second season. The shoot fresh weight per plant was $14.8 \%$ and $4.61 \%$ greater, aerated treatment than in DI and SDI respectively, for the first season, while it was greater by $37.6 \%$ and $1.94 \%$ for the second season. Data from this study indicate that potato yield can be improved under SDI if the drip water is aerated.
\end{abstract}

\section{INTRODUCTION}

otato rates fourth among the world's agricultural products in
production volume (Faberio et al., 2001). According to World
Potato Center's research, worldwide demand for potatoes will
exceed that of rice, wheat, or corn by 2020 .

\footnotetext{
*Associate Professor of Agriculture Eng. - Faculty of Agric. - Cairo Univ. *** Associate Professor of Vegetable - Faculty of Agric. - Cairo Univ. ${ }^{* * * *}$ Assistant Professor of Agriculture Eng. - Faculty of Agric. - Cairo Univ.
} 
The total food value of potato per acre is high. The total caloric contribution of potato to the world food supply will remain less than these cereal crops due to higher water content of the potato.

Currently, world food production depends heavily on irrigated agriculture. Only $20 \%$ of the world's farmland is irrigated, but that farmland produces $40 \%$ of the world's food supply (Howell, 2001). The highest yields obtained from irrigation are more than double the highest yields for rainfed agriculture.

In spite of this, it is very unlikely that irrigated agriculture as it is currently practiced can provide food for the projected increased food demand with population growth to 9 billion by 2050 it will need to encompass increased irrigation efficiency and enhanced use efficiency of other production inputs (Horrigan et al., 2002).

In spite of the great scope for, and adoption of, SDI, in itself it is not an ideal irrigation system. By the very fact that water is continuously emitted, for durations that vary depending upon soil type, crop, and evaporative demand, a part of the root zone in SDI, particularly in heavy clay soils, is purged of soil water and therefore experiences insufficient oxygen for root and microbial respiration and root growth. Quite evidently the point source application of irrigation water with SDI will impose a great impact on the soil moisture gradient and on root activity as affected by the overall soil oxygen distribution pattern. Indeed, Silberbush et al. (1979) showed how the root system of trickle irrigated crops was concentrated on the periphery of the irrigated soil volume, in line with data that showed a low oxygen diffusion rate in the central portion of the irrigated soil volume. Nevertheless, Bar-Yosef et al. (1989) and Hutmacher et al. (1998) found roots still to be concentrated around emitters in corn and cotton crops, for once air returns to that zone it will be the zone most favorably supplied by water. Roots preferentially colonize the soil volume at the depth of the emitters in SDI crops (Machado et al., 2003), not only because that soil volume has preferential supply of water, but also because the fertilizer requirements of the crops are frequently supplied together in trickle irrigation water.

Oxygation is the process of aerating irrigation water and employing SDI to deliver it to the root zone. Hyper-aerating irrigation water to increase 
the oxygen concentration is accomplished by either mixing air or by mixing peroxides such as hydrogen peroxide $\left(\mathrm{H}_{2} \mathrm{O}_{2}\right)$ with irrigation water before it is distributed through the irrigation lines. Oxygation offers plant roots and soil biota extra oxygen with water during, or prior to, finishing, each irrigation cycle when soil air has been replaced by irrigation water. With the current oxygation technology, the additional oxygen is provided directly into the rhizosphere during irrigation with air injection into the irrigation stream (Goorahoo et al., 2002), or close to the end of each irrigation cycle as with hydrogen peroxide injection (Huber, 2000).

Soil aeration and the effect of soil hypoxic conditions on plants have been studied for decades (Grable, 1966; Armstrong, 1979; Glinski and Stepniewski, 1985; Bhattarai et al., 2005b). Also, several means of improving soil aeration have been developed, including: improving soil structure through tillage (Abu-Amdeh, 2003), creating artificial aeration pathways (Ben-Gal et al., 2004; MacDonald et al., 2004), irrigation and drainage management (Camp, 1998; Ayars et al., 1999) and plant selection for tolerance (Stepanova et al., 2002). In particular, three major methods for enriching the root zone with $\mathrm{O}_{2}$ by subsurface trickle irrigation (oxygenated SDI) have been proposed: forced aeration, i.e., pumping pressurized air into the trickle lines (Melsted et al., 1949; Busscher, 1982), sucking air (bubbles) into the irrigation water entering the trickle lines (Goorahoo et al., 2002; Bhattarai et al., 2004, 2006; Maestre-Valero and Martinez-Alvarez, 2010; Bonachela et al., 2010), and adding various peroxides (e.g., $\mathrm{H}_{2} \mathrm{O}_{2}$, urea peroxide, potassium peroxide) to the irrigation water (Melsted et al., 1949; Herr and Jarrel, 1980; Bryce et al., 1982; Bhattarai et al., 2004; Urrestarazu and Mazuela, 2005). Most of these studies reported impressive yield increases for several crops and soil types, but none of the proposed methods has been established in agricultural practice, and it is likely that hypoxic root zones still reduce yields in some circumstances.

The amount of air present in the soil is directly influenced by soil texture. Aggregate size and degree of compaction directly influence the volumetric air content of soil (Fernhout and Kurtz, 1999), for compacted soils in general have reduced pore space. Smaller soil particles (such as silt and clay) reduce soil aeration because they pack 
together very tightly, directly limiting the air spaces between them (Rengasamy, 2000) and indirectly as they hold more water against drainage forces. Larger soil particles (sand), aggregates, and organic matter increase soil aeration because they leave gaps in the soil volume that can be easily drained and filled by air (Cogger et al., 1992). In sandy soils at field capacity, soil air comprises $25 \%$ or more on a soil volumetric basis. However, if there is too much natural soil aeration, evaporation and leaching would rise and the soil would soon dry out (Brady and Weil, 1999; Fernhout and Kurtz, 1999). In loamy soils, the volumetric air content is between 15 and 20\%, and in clayey soils that tend to retain the most water, it can fall below $10 \%$ of the total soil volume (Peverill, 1999) at field capacity.

In the main, benefits to oxygation accrue on heavy soil, but where trialled on lighter textured fine sandy loam soils, benefits have been notable (Goorahoo et al., 2002). Tape depths for SDI range from 0.2 to $0.7 \mathrm{~m}$ (Camp, 1998), with the depth optimized for local conditions, and generally deeper for multiple year use. In a production system where the trickle tape was placed $5 \mathrm{~cm}$ below the soil surface, forced air did not result in growth or yield benefit (Heuberger et al., 2001), but benefits to oxygation are unlikely to be influenced by deeper tape depth, for the additional oxygen is made available close to the emitter and root mass. Experiments by Goorahoo et al. (2002) and Heuberger et al. (2001) showed oxygation benefits with trickle tape at $12-15 \mathrm{~cm}$ depth, and studies by Bhattarai et al. (2004) illustrate oxygation benefits at tape depth from $8 \mathrm{~cm}$ to $25-30 \mathrm{~cm}$. Field data (Goorahoo et al., 2002) with bell pepper showed that the increase in production due to aeration reached a maximum value at $25 \mathrm{~m}$ from the aeration source. Yield then declined along the next $35 \mathrm{~m}$, equaling at the end of the row the yield of non-aerated plots. Such a decline may be acceptable under the shorter row lengths in the glasshouse industry, but emitter design may need to be modified to induce greater uniformity for extensive agriculture. Leaf chlorophyll concentration increases with oxygation, and specific leaf area (SLA) tends to decrease (Bhattarai et al., 2004). Greater leaf chlorophyll concentration and SLA have been correlated with the potential to accumulate high plant biomass (Terauchi et al., 2001). 
In oxygation (venturi and hydrogen peroxide) trials with tomato, soybean and cotton on a heavy clay soil, average yield increases of 12,84 , and $21 \%$, respectively, were achieved compared to the control (Bhattarai et al., 2004). Similarly, in a field experiment at the Centre for Irrigation Technology, in a loam and sandy loam soil, oxygation (venturi) led to a $33 \%$ increase in bell pepper count and a 39\% increase in total fruit weight (Goorahoo et al., 2002). Likewise, in a field experiment on a soil with air-filled porosity at field capacity of $6 \%$ with cauliflower conducted in Germany using trickle tape at $15 \mathrm{~cm}$ depth, total dry matter and percentage of large curds tended to be higher with forced injection of atmospheric air (45 min at $50 \mathrm{kPa}$ after each irrigation and after rainfall if exceeding $10 \mathrm{~mm}$ ) compared with no aeration. In the same experiment, sweet corn produced a higher proportion of marketable cobs with aeration, and of the cobs unsuitable for fresh market, a higher proportion was suitable for industrial processing.

Although recognized for its greater WUE than other forms of irrigation, the WUE of SDI is further improved by oxygation. Hypoxia that restricts root growth reduces the ability of the root system to capture water, thereby predisposing greater volumes to drainage, leakage, and contamination of ground water, with concomitant loss of WUE. Oxygation promotes root growth in the rooting zone of SDI crops, and can reduce some of the undesirable deep drainage. Season-long water use efficiency was considerably higher with oxygation by $11 \%$ (39.1 versus $35.2 \mathrm{~g} \mathrm{~L}^{-1}$ ) for tomato, by $70 \%$ (3.65 versus $2.15 \mathrm{~g} \mathrm{~L}^{-1}$ ) for vegetable soybean, and by $18 \%$ ( 0.45 versus $\left.0.38 \mathrm{~g} \mathrm{~L}^{-1}\right)$ for cotton on a heavy clay soil (Bhattarai et al., 2004; 2005a) and by $36 \%(1.463$ versus $0.937 \mathrm{~kg}$ $\mathrm{m}^{-3}$ ) for corn on a sandy clay loam soil (Abuarab et al., 2013), the other measures of WUE (e.g., the quotient of leaf net photosynthesis and transpiration) were also higher with oxygation (Bhattarai et al., 2004). Although data on the instantaneous WUE showed that oxygated crops were more conservative in their water use per unit of $\mathrm{CO}_{2}$ fixed in photosynthesis, overall because of greater canopy transpiration they were greater users of water, with all the benefits that brought to the hypoxic soil environment. 
The major goal of this study was to evaluate the technical feasibility of injection of ambient air into a subsurface trickle irrigation tape, as a best management practice for improving growth characteristics, crop production and water use efficiency of potato.

\section{MATERIALS AND METHODS}

\section{Location and soil of experimental field plot}

A field study was conducted from October to February 2012-2013 and 2013-2014 at Research Unit of Agricultural Engineering Department (latitude $30.0861 \mathrm{~N}$, and longitude $31.2122 \mathrm{E}$, and mean altitude $70 \mathrm{~m}$ above sea level), Faculty of Agricultural, Cairo University, Egypt. Soil samples from surface down to $60 \mathrm{~cm}$ at $20 \mathrm{~cm}$ interval were collected. Hydrometer method was followed to determine the sand, silt and clay percentage of soil. The soil of the experimental area was deep, welldrained sandy clay loam (Table 1). Irrigation water was obtained from a deep well (60 $\mathrm{m}$ depth from the soil surface) located in the experimental area, with $\mathrm{pH} 7.2$, and an average electrical conductivity of $0.83 \mathrm{dS} \mathrm{m}^{-1}$. Weather data of the experimental site for 2 years 2012-2013 and 20132014 (Table 2).

Table 1. Some physical and chemical properties of the experimental soil

\begin{tabular}{ccccccc}
\hline $\begin{array}{c}\text { Soil } \\
\text { depth } \\
(\mathbf{c m})\end{array}$ & Texture & $\begin{array}{c}\text { Field } \\
\text { capacity } \\
\left(\mathbf{c m}^{\mathbf{3}} \mathbf{c m}^{-\mathbf{3}}\right)\end{array}$ & $\begin{array}{c}\text { Wilting } \\
\text { point } \\
\left(\mathbf{c m}^{\mathbf{3}} \mathbf{c m}^{-\mathbf{3}}\right)\end{array}$ & $\begin{array}{c}\text { Bulk } \\
\mathbf{d e n s i t y} \\
\left(\mathbf{g ~ c m}^{-3}\right)\end{array}$ & $\mathbf{p H}$ & $\begin{array}{c}\mathbf{E C} \\
\left(\mathbf{d S ~ m}_{\mathbf{e}} \mathbf{- 1}\right)\end{array}$ \\
\hline $0-20$ & SCL & 42.07 & 14.43 & 1.29 & 7.74 & 2.43 \\
$20-40$ & SCL & 41.80 & 14.91 & 1.31 & 7.69 & 1.92 \\
$40-60$ & SCL & 38.96 & 17.15 & 1.33 & 7.81 & 1.78 \\
\hline
\end{tabular}

\section{System installation and experimental treatments}

A field plot of size $67.5 \mathrm{~m} \times 30 \mathrm{~m}$ was selected for experimental studies. The field plot was divided into nine equal plots of $7.5 \mathrm{~m} \times 30 \mathrm{~m}$. Each plot was including 10 rows $0.75 \mathrm{~cm}$ apart, representing a single treatment. The experiment was laid out following the split plot design with 3 treatments (surface trickle irrigation $\left(\mathrm{I}_{1}\right)$, subsurface trickle irrigation $\left(\mathrm{I}_{2}\right)$ and Air injection under subsurface trickle irrigation $\left(\mathrm{I}_{3}\right)$ ) and 3 replications $\left(\mathrm{R}_{1}, \mathrm{R}_{2}\right.$ and $\left.\mathrm{R}_{3}\right)$ of each treatment (Fig. 1). Installation 
of the SDI system commenced in October 2012 with control facility, which included hydro cyclone filter, screen filter, back flush mechanisms, fertilizer injection system, i.e. venture. Care was taken to place the trickle tape straight in the ridges with openings on the upper side of the trickle tapes. The layout indicating different treatments is shown in Fig. (1).

Tubers of $30 \mathrm{~g}$ weight of potato (var. Diamont) was sown at the depth of $10 \mathrm{~cm}$ in the raised ridges prepared during the third week of October at a tuber and ridge spacing of $20 \mathrm{~cm} \times 75 \mathrm{~cm}$. The base width and height of ridges were kept 60.0 and $30.0 \mathrm{~cm}$, respectively.

Table 2. Monthly climatic data for the growing seasons of the experimental area

\begin{tabular}{cccccccc}
\hline \multirow{2}{*}{ Year } & \multirow{2}{*}{$\begin{array}{c}\text { Climate } \\
\text { parameter }\end{array}$} & \multicolumn{7}{c}{ Month } \\
\cline { 3 - 8 } $2012-$ & Oct. & Nov. & Dec. & Jan. & Feb. & Mar. \\
\hline 2013 & $\mathrm{~T}_{\min .}\left({ }^{\circ} \mathrm{C}\right)$ & 18.55 & 15.84 & 13.97 & 12.64 & 12.25 & 12.21 \\
& $\mathrm{~T}_{\max }\left({ }^{\circ} \mathrm{C}\right)$ & 29.56 & 26.50 & 24.53 & 23.11 & 22.63 & 22.71 \\
& $\mathrm{~T}_{\text {ave }}\left({ }^{\circ} \mathrm{C}\right)$ & 23.83 & 20.94 & 18.99 & 17.52 & 17.07 & 17.08 \\
& $\mathrm{RH}(\%)$ & 55.29 & 59.80 & 62.75 & 61.90 & 61.12 & 60.00 \\
& Sun shine & 11.2 & 10.6 & 10.1 & 10.3 & 11.2 & 11.7 \\
$(\mathrm{~h})$ & & & & & & \\
\hline $2013-$ & $\mathrm{T}_{\min .}\left({ }^{\circ} \mathrm{C}\right)$ & 22.2 & 17.8 & 9.1 & 7.3 & 7.2 & 8.2 \\
& $\mathrm{~T}_{\max }\left({ }^{\circ} \mathrm{C}\right)$ & 34.4 & 29.4 & 22.6 & 24.1 & 26.4 & 30.3 \\
& $\mathrm{~T}_{\text {ave }}\left({ }^{\circ} \mathrm{C}\right)$ & 28.4 & 23.4 & 19.7 & 15.3 & 16.4 & 17.6 \\
& $\mathrm{RH}(\%)$ & 60 & 69 & 63.4 & 66 & 56 & 56 \\
& Sun shine & 11.4 & 10.7 & 10.4 & 10.5 & 11.3 & 11.9 \\
$(\mathrm{~h})$ & & & & & & \\
\hline
\end{tabular}

Trickle tape of $0.3 \mathrm{~mm}$ thickness (T-Tape, Australia, model TSX 515-30250) was buried manually at depths of $20 \mathrm{~cm}$ in the middle of ridges formed for sowing of potato under different treatments. The hydraulic characteristics of installed trickle system are given in Table 3. The installed trickle system had drippers spaced at $30 \mathrm{~cm}$ each with an application rate of $250 \mathrm{Lph} / 100 \mathrm{~m}$. 


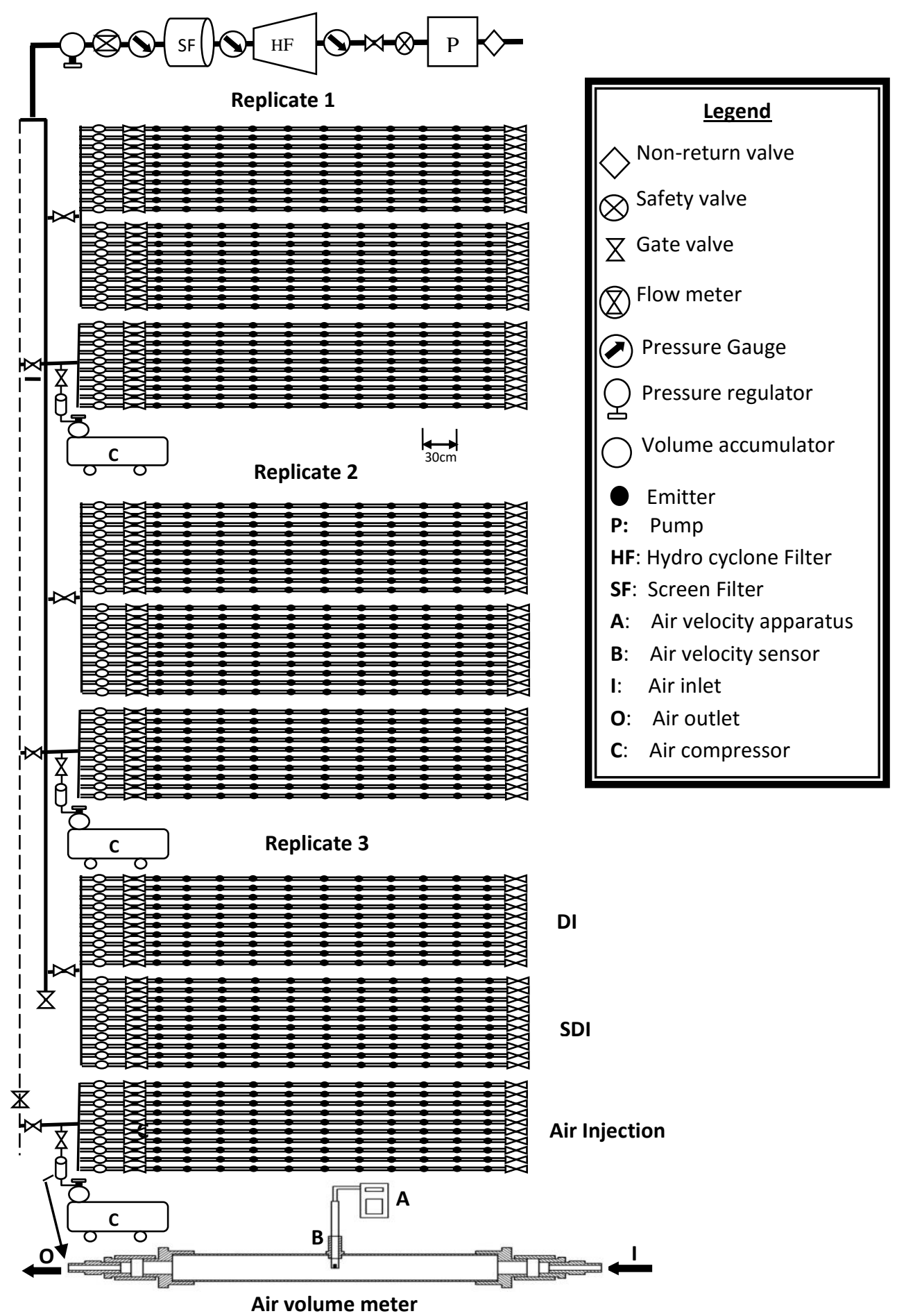

Figure 1. Hydraulic diagram of the microirrigation system, air injection unit, and treatments 
Time domain reflectometry (TDR) was used in this study for determination of soil water content. Three access tubes, one at the middle of ridge and two at 15.0 and $30.0 \mathrm{~cm}$ away from the middle of ridge were installed. Access tubes were placed at the middle of the row up to a depth of $0.60 \mathrm{~m}$ and water content (volumetric) was measured in all treatments. The root zone soil moisture was calculated for each soil based on the difference between field capacity and measured soil moisture content. For the whole growing season irrigation depth was determined to replenish $100 \%$ of plant available water in the root zone.

\section{Nutrient management}

Fertilizers were consisting of $180 \mathrm{~kg} \mathrm{~N} \mathrm{ha}^{-1}, 100 \mathrm{~kg} \mathrm{P}_{2} \mathrm{O}_{5} \mathrm{ha}^{-1}$ and $150 \mathrm{~kg}$ $\mathrm{K}_{2} \mathrm{O}$ ha $^{-1}$. The potassium was applied in two splits (half at planting and half at earthing up) because this practice gives better results than if the entire doses were applied at planting (Phillips et al., 2004). Following the recommended practice of fertilizer application, nitrogen was applied into two split doses (one-third at planting and two-third at crop emergence stage).

Table 3. Hydraulic characteristic of the trickle irrigation system

\begin{tabular}{llc}
\hline Irrigation system & Characteristics & Description \\
\hline Trickle Tape & Wall thickness $(\mathrm{mm})$ & 0.3 \\
& Tape inner diameter $(\mathrm{mm})$ & 16 \\
& Minimum operating pressure $(\mathrm{kPa})$ & 30 \\
& Maximum operating pressure $(\mathrm{kPa})$ & 105 \\
& Dripper discharge $(\mathrm{Lph})$ & 0.75 \\
& Spacing between two drippers $(\mathrm{cm})$ & 30.0 \\
& Spacing between two tapes $(\mathrm{cm})$ & 75.0 \\
& Depth of placement of trickle tape $(\mathrm{cm})$ & 20.0 \\
\hline
\end{tabular}

\section{Estimation of uniformity of trickle system}

Tests for uniformity of water application the trickle system were carried out, in the month of October every year. For each testing, 30 drippers were selected from head, middle and tail ends of trickle tape, randomly. Uniformity of water application was determined from the dripper outflow collected in cans for a known duration. The uniformity of water application was calculated from the statistical distribution of dripper flow 
rates in terms of coefficient of variation (CV) and distribution uniformity (DU) using Eqs. (1) and (2), as follows:

$C V=\frac{s}{q}$

$D U=\left(\frac{q_{\text {lq }}}{q}\right) \times 100$

Where $\mathrm{s}$ is the standard deviation of drippers discharge (Lph); q the mean dripper flow rate (Lph) and $\mathrm{q}_{\mathrm{lq}}$ is the mean of lowest one-fourth of drippers discharge (Lph). Five microirrigation uniformity classifications, ranging from excellent to unacceptable, recognized by the American Society of Agricultural Engineers (ASAE, 1996 a, b) were used to evaluate the DI and SDI systems.

\section{Air injection}

An air compressor and an air volume meter were used as air-injector unit. They were installed in-line immediately after a gate valve. The air volume meter consists of a $1 \mathrm{~m}$ length pipe with a diameter of 2 inches, and is used to transform the flow from turbulent to laminar. An air velocity sensor is installed in the centre of the pipe and is used to measure the average velocity (Fig. 1). This way can control the amount of air injected into the irrigation line ( $12 \%$ air by volume of water). Aerated water was delivered to the soil through drippers. The water flow was decreased when air was injected and then the time of irrigation was increased to compensate the decrement of water flow.

\section{Data recording}

At the day of final harvest on 28 February (110 days after planting (DAP)), 18 plants were harvested from each plot by taking six plants from each of the beginning, middle and end of the plot respectively, for yield mass determination. Total fresh weight of the tubers was determined (kg per plant) and the tuber was dried at $85{ }^{\circ} \mathrm{C}$ for $24 \mathrm{~h}$ to determine the carbohydrates and sugars, soluble and non-soluble. One plant per plot was harvested for determination of shoot fresh weight $(\mathrm{g})$ and shoot dry weight (g). The chlorophyll was measured by using "Minolta Chlorophyll Meter", SPAD-502 (Spectrum Technologies). The 
data for plant height, number of aerial stems, fresh weight per plant and dry weight per plant was derived from final plant harvest.

Actual evapotranspiration within the growing period was estimated from the soil water balance from the following equation:

$\mathrm{ET}=\mathrm{I}+\mathrm{P} \pm \Delta \mathrm{SW}-\mathrm{Dp}-\mathrm{R}$

Where ET is the evapotranspiration $(\mathrm{mm})$, I the amount of irrigation water applied $(\mathrm{mm}), \Delta \mathrm{SW}$ the soil water content changes $(\mathrm{mm}), \mathrm{Dp}$ the deep percolation $(\mathrm{mm})$, and $\mathrm{R}$ is the amount of runoff $(\mathrm{mm})$. Since the amount of irrigation water was controlled, deep percolation and runoff were assumed to be negligible. Water-use efficiency (WUE) and irrigation water-use efficiency (IWUE) values were calculated with Eqs. (4) and (5), respectively (Howell et al., 1990).

$\mathrm{WUE}=\left(\frac{E_{y}}{E_{t}}\right) \times 100$

Where WUE is the water use efficiency $\left(\mathrm{t} \mathrm{ha} \mathrm{mm}^{-1}\right)$; $\mathrm{E}_{\mathrm{y}}$ is the economical yield $\left(\mathrm{t} \mathrm{ha}^{-1}\right)$; $\mathrm{E}_{\mathrm{t}}$ is the plant water consumption, $\mathrm{mm}$.

$$
\text { IWUE }=\left(\frac{\mathrm{E}_{\mathrm{y}}}{\mathrm{I}_{\mathrm{r}}}\right) \times 100
$$

Where IWUE is the irrigation water use efficiency $\left(\mathrm{t} \mathrm{ha}^{-1} \mathrm{~mm}^{-1}\right), \mathrm{E}_{\mathrm{y}}$ is the economical yield $\left(\mathrm{t} \mathrm{ha}^{-1}\right), \mathrm{I}_{\mathrm{r}}$ is the amount of applied irrigation water (mm).

\section{Statistical Analyses}

Statistical analyses were carried out using the GLM (General Linear Model) procedure of the SPSS statistical package. The model was used for analyzing growth characteristics, yield, WUE, and IWUE as fixed effects for the irrigation treatments and growing seasons and the interactions between them, and the replications as error term (Snedecor and Cochran 1976). The probability level for determination of significance was 0.05 . 


\section{RESULTS AND DISCUSSIONS}

\section{Irrigation and yield}

The characteristics of water use and yield showed a significant differences between seasons $\left(\mathrm{S}_{1}\right)$ and $\left(\mathrm{S}_{2}\right)$ except for water use (ET) and irrigation water use efficiency (IWUE), on the other hand there was a significant differences between irrigation treatments for air injection treatment $\left(\mathrm{I}_{3}\right)$ and both DI $\left(\mathrm{I}_{1}\right)$ and $\mathrm{SDI}\left(\mathrm{I}_{2}\right)$, while for the interaction between seasons and irrigation treatments there were significant differences between the aerated and non-aerated treatments (Table 4).

Table 4. Total irrigation water amount (I), plant water consumption (ET), yield, irrigation water use efficiency (IWUE) and water use efficiency (WUE) of potato for different growing seasons and irrigation treatments.

\begin{tabular}{|c|c|c|c|c|c|}
\hline Treatments & $\underset{\left(\mathbf{m}^{3} \mathbf{h a}^{-1}\right)}{\mathbf{I}}$ & $\underset{\left(\mathbf{m}^{\mathbf{3}} \mathbf{h a}^{-1}\right)}{\mathbf{E T}}$ & $\begin{array}{c}\text { Yield } \\
\left(\text { ton ha }^{-1}\right)\end{array}$ & $\begin{array}{c}\text { IWUE } \\
\left(\mathbf{k g ~ m}^{-3}\right)\end{array}$ & $\begin{array}{c}\text { WUE } \\
\left(\mathrm{kg} \mathrm{m}^{-3}\right)\end{array}$ \\
\hline $\mathbf{S}_{1}$ & $6259.760 \mathrm{~b}$ & 5987.440 & $33.677 \mathrm{a}$ & 5.451 & $5.666 \mathrm{a}$ \\
\hline $\mathbf{S}_{2}$ & $6277.010 \mathrm{a}$ & 5968.047 & $32.487 \mathrm{~b}$ & 5.243 & $5.510 \mathrm{~b}$ \\
\hline LSD & 15.50 & NS & 0.693 & NS & 0.1095 \\
\hline $\mathbf{I}_{1}$ & $6713.955 \mathrm{a}$ & $6377.260 \mathrm{a}$ & $28.372 \mathrm{c}$ & $4.242 \mathrm{c}$ & $4.450 \mathrm{c}$ \\
\hline $\mathbf{I}_{2}$ & $6372.510 \mathrm{~b}$ & $6062.440 \mathrm{~b}$ & $33.335 \mathrm{~b}$ & $5.235 \mathrm{~b}$ & $5.478 \mathrm{~b}$ \\
\hline $\mathbf{I}_{3}$ & $5718.690 \mathrm{c}$ & $5493.530 \mathrm{c}$ & $37.538 \mathrm{a}$ & $6.565 \mathrm{a}$ & $6.835 \mathrm{a}$ \\
\hline LSD & 9.429 & 10.87 & 1.103 & 0.07292 & 0.2019 \\
\hline $\mathbf{S}_{1} \mathbf{I}_{1}$ & $6697.210 \mathrm{~b}$ & $6358.120 \mathrm{~b}$ & $30.157 \mathrm{e}$ & $4.533 \mathrm{e}$ & $4.740 \mathrm{~d}$ \\
\hline $\mathbf{S}_{1} \mathbf{I}_{2}$ & $6372.400 \mathrm{c}$ & $6077.090 \mathrm{c}$ & $32.540 \mathrm{~d}$ & $5.110 \mathrm{~d}$ & $5.317 \mathrm{c}$ \\
\hline $\mathbf{S}_{1} \mathbf{I}_{3}$ & $5709.670 \mathrm{e}$ & $5527.110 \mathrm{e}$ & $38.333 \mathrm{a}$ & $6.710 \mathrm{a}$ & $6.940 \mathrm{a}$ \\
\hline $\mathbf{S}_{2} \mathbf{I}_{1}$ & $6730.700 \mathrm{a}$ & $6396.400 \mathrm{a}$ & $26.587 \mathrm{f}$ & $3.950 \mathrm{f}$ & $4.160 \mathrm{e}$ \\
\hline $\mathbf{S}_{2} \mathbf{I}_{2}$ & $6372.620 \mathrm{c}$ & $6047.790 \mathrm{~d}$ & $34.130 \mathrm{c}$ & $5.360 \mathrm{c}$ & $5.640 \mathrm{~b}$ \\
\hline $\mathbf{S}_{2} \mathbf{I}_{3}$ & $5727.710 \mathrm{~d}$ & $5459.950 \mathrm{f}$ & $36.743 \mathrm{~b}$ & $6.420 \mathrm{~b}$ & $6.730 \mathrm{a}$ \\
\hline LSD & 13.34 & 15.37 & 1.559 & 0.1031 & 0.2855 \\
\hline
\end{tabular}

Note: Numbers followed by different letters with in the growing seasons and irrigation treatments are statistically different $(\mathrm{P}<0.05)$. 
There was a $14.75 \%$ and $10.4 \%$ decrease in irrigation water (I) of potatoes, in the air injection treatment $\left(\mathrm{S}_{1} \mathrm{I}_{3}\right)$ comparing with non-aerated treatments trickle irrigation $\left(\mathrm{S}_{1} \mathrm{I}_{1}\right)$ and subsurface trickle irrigation $\left(\mathrm{S}_{1} \mathrm{I}_{2}\right)$, respectively, for the first season, while it was lower by $14.9 \%$ and $10.12 \%$ than $S_{2} I_{1}$ and $S_{2} I_{2}$, respectively, for the second season. While the water use (ET) was $13.1 \%$ and $9.05 \%$ lower, in $\left(\mathrm{S}_{1} \mathrm{I}_{3}\right)$ treatment than in $\mathrm{S}_{1} \mathrm{I}_{1}$ and $\mathrm{S}_{1} \mathrm{I}_{2}$ treatments, respectively, for the first season, while it was lower by $14.64 \%$ and $9.72 \%$ than $S_{2} I_{1}$ and $S_{2} I_{2}$ treatments respectively, for the second season (Table 4).

The yield was $27.11 \%$ and $17.8 \%$ greater, in the air injection treatment $\left(\mathrm{S}_{1} \mathrm{I}_{3}\right)$ comparing with non-aerated treatments trickle irrigation $\left(\mathrm{S}_{1} \mathrm{I}_{1}\right)$ and subsurface trickle irrigation $\left(S_{1} I_{2}\right)$, respectively, for the first season, while it was greater by $38.2 \%$ and $7.66 \%$ than $S_{2} I_{1}$ and $S_{2} I_{2}$, respectively, for the second season. The percentage increases observed in this study can potentially translate into a projected increase benefits per hectare for the farmer depending on the wholesale price of potato (Table 4).

The IWUE was $48.03 \%$ and $31.31 \%$ greater, in the air injection treatment $\left(\mathrm{S}_{1} \mathrm{I}_{3}\right)$ comparing with non-aerated treatments $\left(\mathrm{S}_{1} \mathrm{I}_{1}\right)$ and $\left(\mathrm{S}_{1} \mathrm{I}_{2}\right)$, respectively, for the first season, while it was greater by $62.53 \%$ and $19.78 \%$ than $S_{2} I_{1}$ and $S_{2} I_{2}$, respectively, for the second season. On the other hand the WUE was $46.41 \%$ and $30.52 \%$ greater, in the air injection treatment $\left(\mathrm{S}_{1} \mathrm{I}_{3}\right)$ comparing with non-aerated treatments $\left(\mathrm{S}_{1} \mathrm{I}_{1}\right)$ and $\left(\mathrm{S}_{1} \mathrm{I}_{2}\right)$, respectively, for the first season, while it was greater by $61.78 \%$ and $19.33 \%$ than $S_{2} I_{1}$ and $S_{2} I_{2}$, respectively, for the second season (Table 4).

The yield improvement under aerated treatment comparing with nonaerated treatments is related to that oxygen $\left(\mathrm{O}_{2}\right)$ is essential for root respiration. Immediately after the roots have been surrounded by water they can no longer respire normally. The liquid impedes diffusion of metabolites such as carbon dioxide and ethylene. This causes the plant to be stunted because ethylene is a growth inhibitor (Arkin, 1981). When air is injected into the water within the root zone, diffusion of ethylene and carbon dioxide away from the roots may be increased. This increased diffusion rate should result in improved growing conditions and so yield. The WUE of SDI is further improved by air injection. Hypoxia that restricts root growth reduces the ability of the root system to capture 
water, thereby predisposing greater volumes to drainage, leakage, and contamination of ground water, with concomitant loss of WUE. Air injection promotes root growth in the rooting zone of SDI crops, and can reduce some of the undesirable deep drainage (Bhattarai et al., 2005b).

\section{Vegetative growth parameters}

The characteristics of vegetative growth showed a significant differences between seasons except for number of aerial stems per plant and weight of tubers per plant, on the other hand there was a significant differences between irrigation treatments for air injection treatment $\left(\mathrm{I}_{3}\right)$ and both DI $\left(\mathrm{I}_{1}\right)$ and SDI $\left(\mathrm{I}_{2}\right)$, while for the interaction between seasons and irrigation treatments most of vegetative parameters were not significant except shoot fresh weight per plant and weight of tubers per plant (Table 5).

Table 5. The vegetative growth parameters of potato in different growing seasons and irrigation treatments.

\begin{tabular}{|c|c|c|c|c|c|c|}
\hline Treatments & $\begin{array}{l}\text { Plant } \\
\text { height } \\
(\mathbf{c m})\end{array}$ & $\begin{array}{l}\text { Number of } \\
\text { aerial stems } \\
\text { per plant }\end{array}$ & $\begin{array}{c}\text { Shoot fresh } \\
\text { weight per } \\
\text { plant (g) }\end{array}$ & $\begin{array}{c}\text { Shoot dry } \\
\text { weight per } \\
\text { plant (g) }\end{array}$ & $\begin{array}{c}\text { Number of } \\
\text { tubers per } \\
\text { plant }\end{array}$ & $\begin{array}{c}\text { Weight of } \\
\text { tubers per } \\
\text { plant }(\mathrm{g})\end{array}$ \\
\hline $\mathbf{S}_{1}$ & $53.422 \mathrm{~b}$ & 2.589 & $379.522 \mathrm{a}$ & $47.478 \mathrm{a}$ & $5.511 \mathrm{a}$ & 739.444 \\
\hline $\mathbf{S}_{2}$ & $55.578 \mathrm{a}$ & 2.511 & $355.678 \mathrm{~b}$ & $44.174 \mathrm{~b}$ & $5.011 \mathrm{~b}$ & 716.367 \\
\hline LSD & 2.105 & NS & 17.11 & 2.378 & 0.2585 & NS \\
\hline $\mathbf{I}_{1}$ & $50.383 \mathrm{~b}$ & $2.317 \mathrm{~b}$ & $318.617 \mathrm{c}$ & $40.295 \mathrm{~b}$ & $4.950 \mathrm{~b}$ & $624.500 \mathrm{c}$ \\
\hline $\mathbf{I}_{2}$ & $54.033 \mathrm{~b}$ & $2.450 \mathrm{~b}$ & $385.783 b$ & $48.495 \mathrm{a}$ & $5.300 \mathrm{ab}$ & $732.933 b$ \\
\hline $\mathbf{I}_{3}$ & $59.083 \mathrm{a}$ & $2.883 \mathrm{a}$ & $398.400 \mathrm{a}$ & $48.495 \mathrm{a}$ & $5.533 \mathrm{a}$ & $826.283 \mathrm{a}$ \\
\hline LSD & 4.306 & 0.242 & 9.841 & 4.369 & 0.3597 & 12.17 \\
\hline $\mathbf{S}_{1} \mathbf{I}_{1}$ & 58.933 & 2.367 & $350.833 \mathrm{c}$ & 44.297 & 5.167 & $661.467 \mathrm{e}$ \\
\hline $\mathbf{S}_{1} \mathbf{I}_{2}$ & 63.733 & 2.500 & $385.000 \mathrm{~b}$ & 48.310 & 5.600 & $712.100 \mathrm{~d}$ \\
\hline $\mathbf{S}_{1} \mathbf{I}_{3}$ & 67.600 & 2.900 & $402.733 \mathrm{a}$ & 49.827 & 5.767 & $844.767 \mathrm{a}$ \\
\hline $\mathbf{S}_{2} \mathbf{I}_{1}$ & 61.833 & 2.267 & $286.400 \mathrm{~d}$ & 36.293 & 4.733 & $587.533 \mathrm{f}$ \\
\hline $\mathbf{S}_{2} \mathbf{I}_{2}$ & 64.333 & 2.400 & $386.567 \mathrm{~b}$ & 48.680 & 5.000 & $753.767 \mathrm{c}$ \\
\hline $\mathbf{S}_{2} \mathbf{I}_{3}$ & 70.567 & 2.867 & $394.067 \mathrm{ab}$ & 47.550 & 5.300 & $807.800 \mathrm{~b}$ \\
\hline LSD & NS & NS & 13.92 & NS & NS & 17.21 \\
\hline
\end{tabular}

Note: Numbers followed by different letters with in the growing seasons and irrigation treatments are statistically different $(\mathrm{P}<0.05)$. 
The plant height was $14.7 \%$ and $6.07 \%$ greater, in the air injection treatment $\left(S_{1} I_{3}\right)$ than in the trickle irrigation $\left(S_{1} I_{1}\right)$ and subsurface trickle irrigation $\left(S_{1} I_{2}\right)$, respectively, for the first season, while it was greater by $14.13 \%$ and $9.7 \%$ than $S_{2} I_{1}$ and $S_{2} I_{2}$, respectively, for the second season. While the number of areal stems per plant was $22.52 \%$ and $16 \%$ greater, in $\left(S_{1} I_{3}\right)$ treatment than in $S_{1} I_{1}$ and $S_{1} I_{2}$ treatments, respectively, for the first season, while it was greater by $26.47 \%$ and $19.46 \%$ than $S_{2} I_{1}$ and $\mathrm{S}_{2} \mathrm{I}_{2}$ treatments, respectively, for the second season. The plant height and number of areal stems were slightly higher in the air injection treatment, although the difference between air injection treatment and both trickle and subsurface trickle irrigation under growing seasons was not significant (Table 5).

The shoot fresh weight per plant was $14.8 \%$ and $4.61 \%$ greater, in $\mathrm{S}_{1} \mathrm{I}_{3}$ treatment than in $S_{1} I_{1}$ and $S_{1} I_{2}$ treatments, respectively, for the first season, while it was greater by $37.6 \%$ and $1.94 \%$ than $S_{2} I_{1}$ and $S_{2} I_{2}$ treatments, respectively, for the second season. However, the shoot dry weight per plant showed no significant difference between the air injection treatment and both trickle and subsurface trickle irrigation (Table 5).

The weight of tubers per plant was $27.7 \%$ and $18.5 \%$ greater, in $\mathrm{S}_{1} \mathrm{I}_{3}$ treatment than in $S_{1} I_{1}$ and $S_{1} I_{2}$ treatments, respectively, for the first season, while it was greater by $37.49 \%$ and $7.17 \%$ than $S_{2} I_{1}$ and $S_{2} I_{2}$ treatments, respectively, for the second season (Table 5).

The improvement of vegetative growth parameters under aerated treatment comparing with water only treatments is related to that poor root respiration reduces the uptake of water and nutrients, and because chemical changes in the soil produce toxins that limit overall plant growth (Fernhout and Kurtz, 1999), poor soil aeration induces a wider effect on plant growth than that confined to root growth. At any given temperature, plant growth rate can be related to the oxygen level in the soil (McLaren and Cameron, 1996). Most species show a decreased growth rate with a reduction in availability of soil oxygen. A primary manifestation of hypoxia is a reduction in stomatal conductance and 
water absorption (Vasellati et al., 2001). This leads to reduced canopy transpiration. Indeed, rates of stem sap flow have been shown to increase with oxygation, an effect that probably has a positive feedback, diminishing the soil water content and thereby increasing oxygen flux from the atmosphere to roots.

\section{Quality parameters}

The characteristics of quality parameters showed a significant difference between seasons, on the other hand there was a significant differences between irrigation treatments for air injection treatment $\left(\mathrm{I}_{3}\right)$ and both trickle irrigation $\left(\mathrm{I}_{1}\right)$ and subsurface trickle irrigation $\left(\mathrm{I}_{2}\right)$, while for the interaction between seasons and irrigation treatments most of quality parameters were significant except chlorophyll (Table 6).

With respect to quality parameters, the specific gravity was $5.1 \%$ and $1,49 \%$ greater, in the air injection treatment $\left(\mathrm{S}_{1} \mathrm{I}_{3}\right)$ than in the trickle irrigation $\left(\mathrm{S}_{1} \mathrm{I}_{1}\right)$ and subsurface trickle irrigation $\left(\mathrm{S}_{1} \mathrm{I}_{2}\right)$ treatments, respectively, for the first season, while it was greater by $8.06 \%$ and $5.49 \%$ than $S_{2} I_{1}$ and $S_{2} I_{2}$, respectively, for the second season. However, the chlorophyll showed no significant difference between the aerated and non-aerated treatments (Table 6).

The total carbohydrates was $40.52 \%$ and $21.24 \%$ greater, in the aerated treatment $\mathrm{S}_{1} \mathrm{I}_{3}$ than non-aerated treatments $\mathrm{S}_{1} \mathrm{I}_{1}$ and $\mathrm{S}_{1} \mathrm{I}_{2}$, respectively, for the first season, while it was greater by $39.10 \%$ and $21.09 \%$ than $\mathrm{S}_{2} \mathrm{I}_{1}$ and $\mathrm{S}_{2} \mathrm{I}_{2}$, respectively, for the second season (Table 6).

The soluble sugar was $21.63 \%$ and $16.12 \%$ greater, in the aerated treatment $\mathrm{S}_{1} \mathrm{I}_{3}$ than non-aerated treatments $\mathrm{S}_{1} \mathrm{I}_{1}$ and $\mathrm{S}_{1} \mathrm{I}_{2}$, respectively, for the first season, while it was greater by $25.72 \%$ and $2.8 \%$ than $S_{2} I_{1}$ and $\mathrm{S}_{2} \mathrm{I}_{2}$, respectively, for the second season. While for Insoluble Sugar there was $42.85 \%$ and $21.82 \%$ greater, in the aerated treatment $S_{1} I_{3}$ than nonaerated treatments $S_{1} I_{1}$ and $S_{1} I_{2}$, respectively, for the first season, while it was greater by $40.12 \%$ and $23.04 \%$ than $S_{2} I_{1}$ and $S_{2} I_{2}$, respectively, for the second season (Table 6). 
Table 6. Specific gravity, chlorophyll, total carbohydrates, soluble sugar and insoluble sugar of potato in different growing seasons and irrigation treatments.

\begin{tabular}{|c|c|c|c|c|c|}
\hline Treatments & $\begin{array}{l}\text { Specific } \\
\text { gravity }\end{array}$ & Chlorophyll & 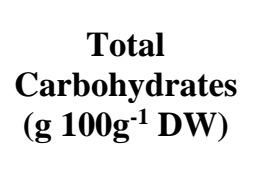 & 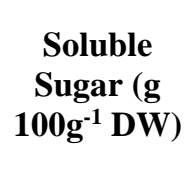 & $\begin{array}{c}\text { Insoluble } \\
\text { Sugar } \\
\left(\mathrm{g} \mathrm{100g^{-1 }}\right. \\
\text { DW) }\end{array}$ \\
\hline $\mathbf{S}_{1}$ & $1.070 \mathrm{~b}$ & $54.067 \mathrm{~b}$ & $52.28 \mathrm{~b}$ & $5.367 \mathrm{~b}$ & $46.91 \mathrm{~b}$ \\
\hline $\mathbf{S}_{2}$ & $1.104 \mathrm{a}$ & $56.867 \mathrm{a}$ & $59.23 \mathrm{a}$ & $6.767 \mathrm{a}$ & $52.36 \mathrm{a}$ \\
\hline LSD & 0.0109 & 2.591 & 1.891 & 0.194 & 0.2190 \\
\hline $\mathbf{I}_{1}$ & $1.053 \mathrm{c}$ & $54.167 \mathrm{~b}$ & $47.10 \mathrm{c}$ & $5.383 \mathrm{c}$ & $41.72 \mathrm{c}$ \\
\hline $\mathbf{I}_{2}$ & $1.085 \mathrm{~b}$ & $55.617 \mathrm{ab}$ & $54.33 \mathrm{~b}$ & $6.150 \mathrm{~b}$ & $48.18 \mathrm{~b}$ \\
\hline $\mathbf{I}_{3}$ & $1.123 \mathrm{a}$ & 56.617 a & $65.83 \mathrm{a}$ & $6.667 \mathrm{a}$ & $59.00 \mathrm{a}$ \\
\hline LSD & 0.0094 & 1.477 & 0.4910 & 0.3036 & 0.4189 \\
\hline $\mathbf{S}_{1} \mathbf{I}_{1}$ & $1.040 \mathrm{~d}$ & 52.200 & $44.00 \mathrm{f}$ & $4.933 \mathrm{c}$ & $39.07 \mathrm{f}$ \\
\hline $\mathbf{S}_{1} \mathbf{I}_{2}$ & $1.077 \mathrm{c}$ & 54.200 & $51.00 \mathrm{~d}$ & $5.167 \mathrm{c}$ & $45.83 \mathrm{~d}$ \\
\hline $\mathbf{S}_{1} \mathbf{I}_{3}$ & $1.093 \mathrm{~b}$ & 55.800 & $61.83 \mathrm{~b}$ & $6.000 \mathrm{~b}$ & $55.83 \mathrm{~b}$ \\
\hline $\mathbf{S}_{2} \mathbf{I}_{1}$ & $1.067 \mathrm{c}$ & 56.133 & $50.20 \mathrm{e}$ & $5.833 \mathrm{~b}$ & $44.37 \mathrm{e}$ \\
\hline $\mathbf{S}_{2} \mathbf{I}_{2}$ & $1.093 \mathrm{~b}$ & 57.033 & $57.67 \mathrm{c}$ & $7.133 \mathrm{a}$ & $50.53 \mathrm{c}$ \\
\hline $\mathbf{S}_{2} \mathbf{I}_{3}$ & $1.153 \mathrm{a}$ & 57.433 & $69.83 \mathrm{a}$ & $7.333 \mathrm{a}$ & $62.17 \mathrm{a}$ \\
\hline LSD & 0.0133 & NS & 0.6944 & 0.4294 & 0.5924 \\
\hline
\end{tabular}

Note: Numbers followed by different letters with in the growing seasons and irrigation treatments are statistically different $(\mathrm{P}<0.05)$.

\section{CONCLUSIONS}

Air injection irrigation systems can increase root zone aeration and add value to grower investments in SDI. The increase in yields and potential improvement in soil quality associated with the root zone aeration implies that the adoption of the SDI-air injection technology primarily as a tool for increasing potato productivity.

These statistically significant results on a small plot ( 0.20 ha.) support reported results obtained on tests conducted on a commercial farm, and 
are sufficiently encouraging to justify follow-up fieldwork on larger plots. Further fieldwork should be performed on various plant types and should include air/water ratio, and soil root zone moisture, temperature, and nutrient status measurements.

Of special interest in the potential application of this air injection technology is the characterization of how the beneficial effect may vary with the length of trickle lines. Subsequent studies should attempt to monitor pressure and velocity changes along the trickle system and correlate these with plant yield and soil parameters.

\section{REFERENCES}

Abu-Amdeh, N. H. 2003. Effect of compaction and deep tillage on soil hydraulic and aeration properties and wheat yield. Communications in Soil Science and Plant Analysis 34, 2277-2290.

Abuarab, M. E., Mostafa, E. and Ibrahim, M. M. 2012. Effect of air injection under subsurface trickle irrigation on yield and water use efficiency of corn in a sandy clay loam soil. Journal of Advanced Research. Article in press.

Arkin, G. F. 1981. Modifying the root environment to reduce crop stress. American Society of Agricultural Engineers, 141-150.

Armstrong, W. 1979. Aeration in higher plants. Advances in Botanical Research 7, 225-332.

ASAE. 1996a. Field Evaluation of Micro Irrigation Systems. EP405.1. ASAE Standards. Amer. Soc. Agric. Engr., St. Joseph, MI, pp. 756-759.

ASAE. 1996b. Design and Installation of Micro Irrigation Systems. EP409. ASAE Standards. Amer. Soc. Agric. Engr., St. Joseph, MI, pp. 792-797.

Ayars, J. E., Phene, C. J., Hutmacher, R. B., Davis, K. R., Schoneman, R. A., Vali, S. S., Mead, R. M. 1999. Subsurface trickle irrigation of row crops: a review of 15 years of research at the water management research laboratory. Agricultural Water Management $42,1-27$. 
Bar-Yosef, B., Sagiv, B. and Markovitz, T. 1989. Sweet corn response to surface and subsurface trickle phosphorus fertigation. Agron. J. 81, 443-447.

Ben-Gal, A., Lazorovitch, N., Shani, U. 2004. Subsurface trickle irrigation in gravel-filled cavities. Vadose Zone Journal 3, 14071413.

Bhattarai, S., Huber, S., and Midmore, D. J. 2004. Aerated subsurface irrigation water gives growth and yield benefits to zucchini, vegetable soybean and cotton in heavy clay soil. Ann. Appl. Biol. 144, 285-298.

Bhattarai, S., Pendergast, L. and Midmore, D. J. 2005a. Oxygation of subsurface trickle irrigated tomato (Lycopersicon esculentum L.) improves yield performance, tolerance to salinity and water use efficiency in normal and saline heavy clay soil. Sci. Hortic.

Bhattarai, S. P., Pendergast, L., Midmore, D. J. 2006. Root aeration improves yield and water use efficiency of irrigated tomato in heavy clay and saline soils. Scientia Horticulturae 108, 278-288.

Bhattarai, S. P., Su, N., Midmore, D. J. 2005b. Oxygation unblocks yield potentials of crops in oxygen-limited soil environments. Advances in Agronomy 88, 313-317.

Bonachela, S., Quesada, J., Acuna, R. A., Magan, J. J., Marfa, O. 2010. Oxyfertigation of a greenhouse tomato crop grown on rockwool slabs and irrigated with treated wastewater: oxygen content dynamics and crop response. Agricultural Water Management 97, 433-438.

Brady, N. C. and Weil, R. R. 1999. Soil aeration and temperature. In "The Nature and Properties of Soils" pp. 265-306. Prentice Hall, New York.

Bryce, J. H., Focht, D. D., Stolzy, L. H. 1982. Soil aeration and plant growth response to urea peroxide fertilization. Soil Science 134, 111-116.

Busscher, W. J. 1982. Improved growing conditions through soil aeration. Communications in Soil Science and Plant Analysis 13, 401-409. 
Camp, C. R. 1998. Subsurface trickle irrigation: a review. Transactions of the American Society of Agricultural Engineers 41, 1353-1367.

Cogger, C. G., Kennedy, P. E. and Carlson, D. 1992. Seasonally saturated soils in the Puget lowland II. Measuring and interpreting redox potentials. Soil Sci. 154, 50-58.

Faberio, C., Martin de Santa Olalla, F., de Juan, J. A. 2001. Yield and size of deficit irrigated potatoes. Agric. Water Manage. 48, 255266.

Fernhout, P. and Kurtz, C. 1999. Garden with Insight v1.0 Help: Aeration. Kurtz-Fernhout Software.

Glinski, J., Stepniewski, W. 1985. Soil Aeration and its Role for Plants. CRC Press, Boca Raton.

Goorahoo, D., Carstensen, G., Zoldoske, D. F., Norum, E., Mazzei, A. 2002. Using air in subsurface trickle irrigation (SDI) to increase yields in bell peppers. International Water Irrigation 22, 39-42.

Grable, A. R. 1966. Soil aeration and plant growth. Advances in Agronomy 18, 57-106.

Herr, E. M. and Jarrel, W. M., 1980. Response of chrysanthemum to urea peroxide. Horticultural Science 15, 501-502.

Heuberger, H., Livet, J. and Schnitzler, W. 2001. Effect of soil aeration on nitrogen availability and growth of selected vegetables preliminary results. Acta Hortic. 563, 147-154.

Horrigan, L., Lawrence, R. S. and Walker, P. 2002. How sustainable agriculture can address the environmental and human health harms of industrial agriculture. Environ. Health Persp. 110, 445-456.

Howell, T. A. 2001. Enhancing water use efficiency in irrigated agriculture. Agron. J. 93, 281-289.

Howell, T. A., Cuence, R. H. and Solomon, K. H. 1990. Crop yield response. In: Hoffman GJ., et al. (Eds.), Management of farm irrigation systems. ASAE, St. Joseph, MI; p. 312.

Huber, S. 2000. New Uses for Trickle Irrigation: Partial Root Zone Drying and Forced Aeration. (M.Sc. Thesis). Technische Universitat Munchen, Munich.

Hutmacher, R. B., Davis, K. R., Vali, S. S. and Peters, M. S. 1998. Root distribution of cotton: Effect of water application amounts under 
subsurface trickle irrigation. In "Proceedings of the Belt wise Cotton Conferences" Vol. 2 (P. Dugger and D. Ritcher, Eds.), pp. 1491-1495. National Cotton Council, Memphis.

MacDonald, J. D., Costello, L. R., Lichter, J. M. and Quickert, D. 2004. Fill soil effects on soil aeration and tree growth. Journal of Arboriculture 30, 19-27.

Machado, R. M. A., Rosario, M.do., Oliveira, G. and Portas, C. A. M. 2003. Tomato root distribution, yield and fruit quality under subsurface trickle irrigation. Plant Soil 255, 333-341.

Maestre-Valero, J. F. and Martinez-Alvarez, V., 2010. Effects of trickle irrigation systems on the recovery of dissolved oxygen from hypoxic water. Agricultural Water Management 97, 1806-1812.

McLaren, R. G. and Cameron, K. C. 1996. Soil aeration and temperature. In "Soil Science: Sustainable Production and Environmental Protection" (R. G. McLaren and K. C. Cameron, Eds.), pp. 105115. Oxford University Press, Auckland.

Melsted, S. W., Krutz, T., Bray, R. 1949. Hydrogen peroxide as an oxygen fertilizer. Agronomy Journal 41, 97.

Peverill, K. I. S., L, A. and Reuter, DJ. (1999). Soil Analysis: An Interpretation Manual. CSIRO Publishing Collingwood, Australia. Phillips, S. B., Warren, J. G., Keahey, D. A., Mullins, G. L. 2004. Nitrogen Management for White Potato Production. Crop, Soil, and Environmental Sciences; Virginia Tech. Publication Number 438012.

Rengasamy, P. 2000. Subsoil constraints and agricultural productivity. J. Indian Soil Sci. Soc. 48, 674-682.

Silberbush, M., Gornat, B. and Goldberg, D. 1979. Effect of irrigation from a point source (trickle) on oxygen flux and on root extension in the soil. Plant Soil. 52, 507-514.

Snedecor, G. W. and Cochran.W. G. 1976. Statistical Methods, Eighth Edition, Iowa State University Press. Ames. p. 286.

Stepanova, A. U., Polyakova, L. I., Dolgikh, Yu. I. and Vartapetian, B.B. 2002. The response of sugarcane (Saccharum officinarum) cultured cells to anoxia and the selection of a tolerant cell line. Russian Journal of Plant Physiology 49, 406-412. 
Terauchi, T., Matsuoka, M., Nakagawa, H. and Nakauo, H. 2001. A breeding index for improving the early growth of sugarcane. JIRCAS Research Highlights 2001. pp. 40-41.

Urrestarazu, M. and Mazuela, P.C. 2005. Effect of slow-release oxygen supply by fertigation on horticultural crops under soilless culture. Scientia Horticulturae 106, 484-490.

Vasellati, V., Oesterhelds, M., Medan, D. and Loreti, J. 2001. Effects of flooding and drought on the anatomy of Paspalum dilatum. Ann. Bot. 88, 1-6.

\section{الملخص العربيى}

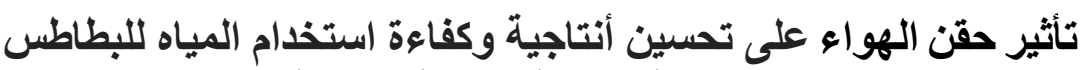
في التربة الرملية الطينية الطميية وكية وكية

| ايهاب عبد المنعم مجدى***

محمد محمد شـاهين*

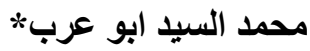

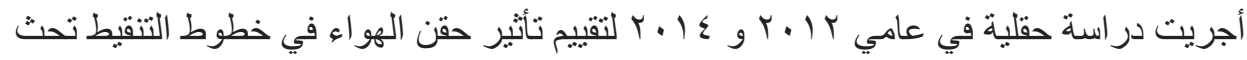
نظام الري بالتنقيط التحت سطحي على نمو و أنتاجية محصول البطاطس. وتمت مقائ مقارنة

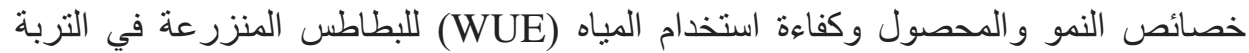

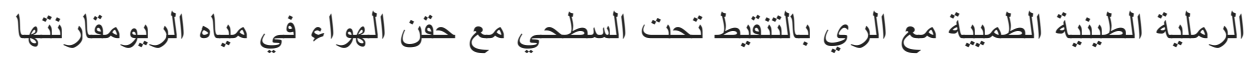

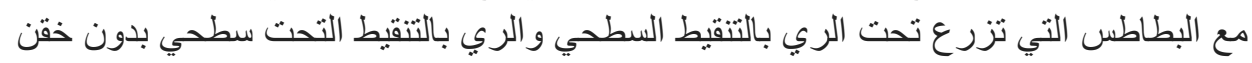

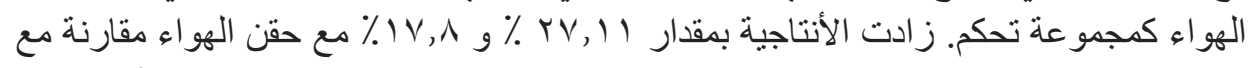

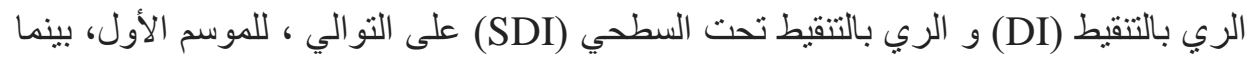

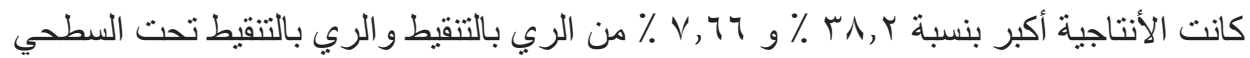

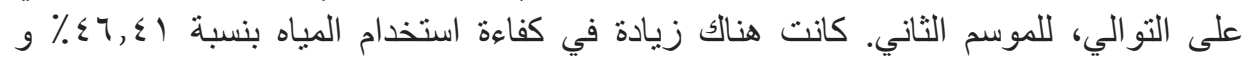

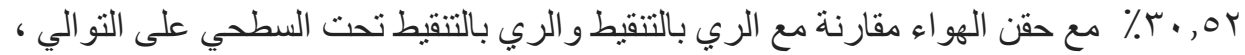

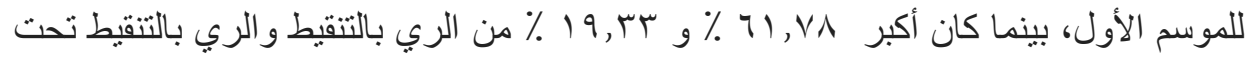

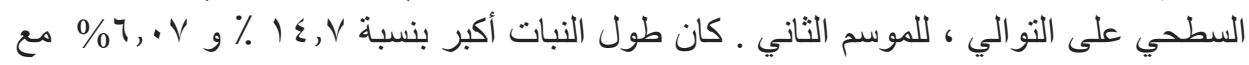

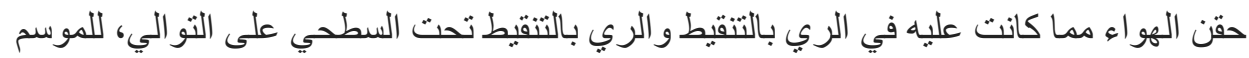

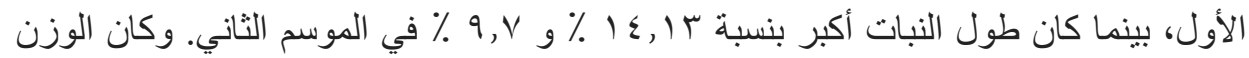

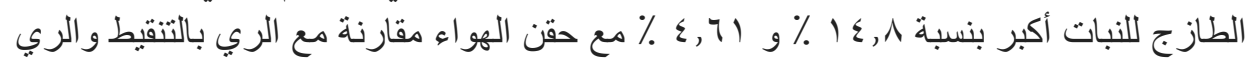

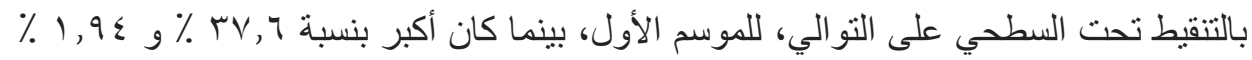

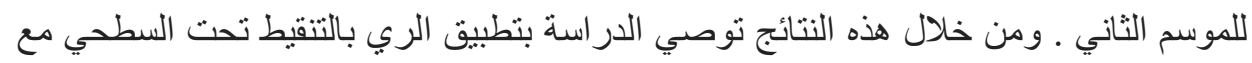

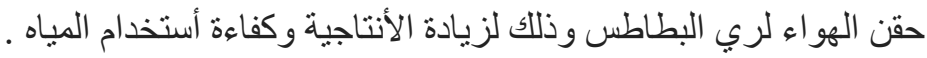

* أستاذ مساعد الهندسة الزراعية ـ كلية الزراعة ـ جامعة القاهرة. * * أستاذ مساعد الخضر - كلية الزراعة ماعة - جامعة القاهرة.

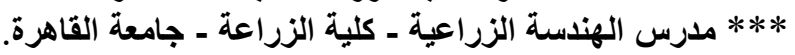

